DOI: https://doi.org/10.53754/iscs.v1i1.13

\title{
PENGARUH ASPEK MANAJEMEN KEUANGAN DAERAH TERHADAP TRANSPARANSI PENGELOLAAN KEUANGAN DAERAH DI LUMAJANG
}

\section{THE EFFECT OF REGIONAL FINANCIAL MANAGEMENT ASPECTS ON TRANSPARENCY OF REGIONAL FINANCIAL MANAGEMENT IN LUMAJANG}

\section{Ari Rachmad \\ Perbanas Jakarta \\ Email: ari.rachmad030@perbanas.id}

\begin{abstract}
This study aims to verify the impact of aspects of regional financial management on the transparency of regional financial management in Lumajang. Primary data assortment was administered by distributing questionnaires. The collected data were then analyzed using linear regression. The study results explain that partially the aspects of regional financial planning, regional financial administration, reporting aspects, and regional financial supervision affect the transparency of regional financial management in Lumajang. Simultaneously the aspects of regional financial planning, aspects of regional financial administration, reporting aspects and aspects of regional financial supervision of the regions affect the transparency of regional financial management in Lumajang.
\end{abstract}

Keywords: Administration, planning, reporting, supervision, transparency.

\section{PENDAHULUAN}

Pemusatan perhatian yang dilakukan oleh pemerintah kepada pengelolaan keuangan daerah dikarenakan banyak perubahan yang muncul dan yang terjadi, di antaranya pemisahan pengelolaan keuangan pusat dan daerah serta ditunjang dengan faktor lain yaitu perluasan daerah Indonesia. Pemerintah pusat memiliki tujuan yang bisa dibilang krusial dalam rangka memberikan jasa dan pelayanan kepada masyarakat, sehingga diperlukanlah akuntansi yang berbeda dengan akuntansi yang beredar di masyarakat pada umumnya.

Dalam pelaksaannya, pemerintah pusat sudah mengeluarkan 2 bentuk peraturan, yaitu undang-undang Nomor 22 tahun 1999 yang membahas pemerintah pusat dan daerah. Ketika sudah dipublikasi kedua UU tersebut ada beberapa peraturan baru tentang pelaksaannya yang dikeluarkan oleh pemerintah. Adapun peraturannya adalah peraturan pemerintah pada tahun 2000 nomor 105 yang membahas tentang pengelolaan serta pertanggung jawaban atas keuangan daerah yang sudah ditinjau menjadi peraturan pemerintah tahun 2005 nomor 56 yang membahas tentang sistem keuangan pemerintah, adapun sistem itu adalah sistem yang mendefinisikan akuntansi pemerintah daerah adalah proses manajemen pencatatan, dan merangkum langkahlangkah mulai dari transaksi hingga moneter sehingga peristiwa yang biasanya bersifat keuangan dalam beberapa cara, termasuk ekonomi yang kuantitasnya bisa dibilang terbanyak dengan sistem pelaporan untuk pengelolaan urusan pemerintahan 
Received: 2021-04-05 Revised: 2021-05-06 Approved: 2021-06-03

berdasarkan prinsip otonomi. Asas dan asas misi pembantuan dari negara Republik Indonesia sendiri tentunya

Arif et.al., (2016:548) menyampaikan bahwa Pengelolaan keuangan daerah merupakan suatu proses yang dilaksanakan oleh pemerintah daerah yang bertujuan untuk mengatur segala sesuatu yang bersifat mengikat dan terkait dengan kegiatan anggaran guna mencapai tujuan pemerintah. Salah satu cara untuk melaksanakan kegiatan ini adalah dengan membawa manfaat yang sangat besar untuk daerah serta masyarakatnya itu sendiri dengan melalui pengelolaan anggaran pemerintah yang efektif lagi mengenai sasaran. Adapun untuk pengelolaan keuangan daerah yang biasanya disandingkan dengan pengelolaan keuangan juga harus dilakukan secara bertanggung jawab dan transparan.

Transparansi dalam pengelolaan keuangan kini menjadi syarat mutlak untuk mewujudkan good government governance yang bertujuan untuk mengurangi dari kegiatan yang menyimpang sehingga merugikan masyarakat secara luas, hal ini bisa dikatakan sebagai pencegahan KKN (Kolusi, Korupsi dan Nepotisme). Namun pada hakikatnya kita masih bisa melihat bahwasanya aspek transparansi ini masih titik terlemah dari manajemen keuangan di daerah itu sendiri, hal ini dikarenakan masih kurangnya dari informasi publik tentang bagaimana penggunaan anggaran daerah secara semestinya serta pelaporan keuangan anggaran pun masih bisa dikatakan tidak relevan dengan peraturan yang ada. Oleh karena itu manajemen keuangan pemerintah haruslah secara aktif maupun pasif agar bisa menjadi anggaran daerah efektif dan akuntanbel yang bisa menjadi harapan pada saat ini untuk mewujudkan pemerintahan yang terpercaya dalam memenuhi hak-hak masyarakat itu sendiri.

Manajemen Keuangan yang berada di daerah merupakan salah satu dari Manajemen pemerintahan daerah juga selain dari Manajemen Kepegawaian dan Manajemen Teknis yang memiliki keterkaitan cukup erat dengan pelayanan publik. Berdasarkan Peraturan Menteri Dalam Negeri Nomor 13 Tahun 2006 yang membahas mengenai Bagaimana Mengelola Keuangan Daerah, dalam peraturan tersebut ada beberapa hal yang menjelaskan "keseluruhan kegiatan yang meliputi perencanaan, pelaksanaan, penatausahaan, pelaporan, pertanggungjawaban, dan pengawasan keuangan daerah adalah pengelolaan atau manajemen keuangan daerah. Di dalam Undang-undang juga tertulis bahwa pengelolaan manajemen keuangan daerah harus berpegang pada azas umum yaitu harus dilaksanakan dengan taat akan peraturan dari undang-undang yang sudah dibuat, ekonomis, efisien, efektif, transparan dan bertanggungjawab dengan memperhatikan asas manfaat bagi masyarakat dan keadilan (Pamungkas, 2013:2). Namun peristiwa yang sudah terjadi akan menimbulkan berbagai masalah yang muncul 
Received: 2021-04-05 Revised: 2021-05-06 Approved: 2021-06-03

karena adanya kesalahan dari pengelolaan dari manajemen keuangan daerah yang kurang baik seperti penggunaan alokasi dana atau dana belanja yang dianggarkan atau digunakan secara tidak tepat, anggaran yang diserap dengan tidak maksimal dan rasa tanggung jawab terhadap penggunaan anggaran yang tidak relevan dan ada hal lain yang menyebabkan hak masyarakat di berbagai daerah tidak terpenuhi dengan baik dan sering diabaikan, tidak bisa dipungkiri bahwa ini sudah terjadi di beberapa daerah di Indonesia termasuk di Kabupaten Lumajang.

Pekerjaan pemerintahan bisa dibilang cukup banyak, seperti pembangunan dan pelayanan publik yang ada di salah satu otonom di Provinsi Jawa Timur adalah pemerintah di Lumajang. Maka dari itu informasi terkait bagaimana mengatur keuangan yang dihasilkan dari Satuan Kerja Perangkat Daerah Lumajang haruslah memiliki sifat yang terbuka dan mudah dijangkau oleh berbagai elemen masyarakat agar masyarakat sendiri bisa berperan dalam proses pengelolaan keuangan yang terpercaya serta transparan. Berbagai usaha telah dilakukan oleh Pemerintah Kabupaten Lumajang. Akan tetapi, komunikasi publik yang termasuk dalam prinsip transparansi belum diterapkan dalam banyak aktivitas pemerintahan. Masyarakat belum tentu dapat mengakses dengan mudah walaupun informasi tersebut sudah dimuat oleh media masa. Adanya salah satu aspek dari kualitas manajemen keuangan yang bertingkat daerah adalah salah satu sebab yang bisa menjadi pengaruh dari sebuah kata transparansi pengelolaan keuangan di Kabupaten Lumajang.

Banyaknya program kerja yang direncanakan instansi di lingkungan kabupaten Lumajang mengakibatkan pengawasan dan pemeriksaan kurang maksimal dan tidak menyeluruh. Selain itu, banyak kesalahan dan penyimpangan yang terjadi diakibatkan oleh rendahnya independensi dan kurangnya kualitas pengawasan di lingkungan kerja pemerintah Kabupaten Lumajang. Rendahnya perhatian dan komitmen para perangkat perintah dalam mendirikan sistem pengendalian yang memiliki kualitas baik dalam setiap lingkungan kerjanya berakibat proses pengawasan yang banyak memakan waktu dan tidak sesuai dengan waktu yang seharusnya.

Studi tentang manajemen keuangan daerah terhadap transparansi pengelolaan keuangan sudah banyak dilakukan oleh beberapa peneliti. Seperti, Chaiprilza Faradina (2016) dengan judul “Pengaruh Aspek Keuangan, Aspek Manajemen, dan Aspek Agunan terhadap Besarnya Persetujuan Pembiayaan pada Petani Kelapa Sawit di Bank Syariah Mandiri". Ia mengungkapkan bahwa secara parsial kebutuhan pembiayaan, pendapatan bersih, nilai likuidasi agunan berpengaruh positif dan signifikan terhadap besarnya persetujuan pembiayaan. Pendidikan dan pengalaman berpengaruh positif dan tidak signifikan terhadap besarnya persetujuan pembiayaan. 
Received: 2021-04-05 Revised: 2021-05-06 Approved: 2021-06-03

Selain itu ada dari Dominikus Ledo dan Sri Ayem (2017). Dalam penelitiannya "Pengaruh Aspek Manajemen Keuangan Daerah Terhadap Transparansi Pengelolaan Keuangan Daerah (Studi Kasus Pada SKPD Daerah Yogyakarta” ia menunjukkan bahwa penyajian laporan keuangan daerah tidak berpengaruh signifikan terhadap transparansi pengelolaan keuangan daerah. Aksesibilitas daerah laporan keuangan berpengaruh signifikan terhadap transparansi keuangan daerah pengelolaan.

Temuan dari penelitian Diana Nova Lintong (2017) “Pengaruh Implementasi Sistem Akuntansi, Pengelolaan Keuangan Daerah Dan Pengawasan Internal Terhadap Kinerja Pemerintah Kota Kotamobagu mengungkapkan bahwa penerapan sistem akuntansi, pengelolaan keuangan daerah dan pengendalian internal secara bersama-sama berpengaruh signifikan terhadap kinerja Pemerintah Daerah dengan kontribusi sebesar $50,5 \%$, sedangkan hanya secara parsial sistem akuntansi dan pengelolaan keuangan daerah yang berpengaruh signifikan terhadap Kinerja Pemerintah Daerah.

Berdasarkan pendahuluan tersebut, peneliti memfokuskan penelitian ini untuk menjawab apakah aspek perencanaan, aspek pelaksanaan, aspek pelaporan, dan aspek pengawasan secara simultan berpengaruh terhadap transparansi pengelolaan keuangan daerah pada pada Satuan Kerja Perangkat Daerah Kabupaten Lumajang; apakah aspek perencanaan keuangan daerah berpengaruh secara parsial terhadap pada Satuan Kerja Perangkat Daerah Kabupaten Lumajang; apakah aspek pelaksanaan keuangan daerah berpengaruh secara parsial terhadap transparansi pengelolaan keuangan daerah pada Satuan Kerja Perangkat Daerah Kabupaten Lumajang.

\section{METODE}

Penelitian ini masuk ke dalam penelitian Kuantitatif. Metode yang digunakan adalah berdasarkan filosofi positif. Adapun untuk pengumpulan data digunakanlah alat penelitian dari sebuah metode analisis data yang bersifat kuantitatif atau sering juga disebut statistik yang sudah umum digunakan dalam pengujian dari hipotesis yang sudah ditentukan sejak awal. Peneliti menggunakan data utama yaitu data yang terkait dengan pengelolaan keuangan daerah dan transparansi pengelolaan keuangan daerah. Data utama adalah informasi yang dikumpulkan secara langsung (Sekarang 2011: 60).

Pengumpulan data mentah dilakukan melalui survei kuesioner. Kuesioner merupakan model pencarian data yang bersifat pertanyaan secara tertulis yang gunanya untuk mencari informasi dari para narasumber secara personal (Arikunto, 2009: 127). Adapun untuk kuesioner ini bersifat tertutup, yaitu pertanyaan dirancang dalam bentuk yang menyediakan opsi. Untuk analisis data mentah yang dikumpulkan melalui kuesioner, maka diperlukan skala likert untuk mengubah data tersebut menjadi data numerik. 
Received: 2021-04-05 Revised: 2021-05-06 Approved: 2021-06-03

Kategori skala likert yang dirancang dalam kuisioner mendapat poin 1-5, dan kategori nilainya ditunjukkan pada tabel di bawah ini.

Tabel 1.1 Kategori Nilai Skor

\begin{tabular}{ccc}
\hline No & Jawaban & Bobot \\
1 & Sangat Setuju & 5 \\
2 & Setuju & 4 \\
3 & Kurang Setuju & 3 \\
4 & Tidak Setuju & 2 \\
5 & Sangat Tidak Setuju & 1 \\
\hline
\end{tabular}

Sumber: Rangkuty (2008:33)

Untuk mengetahui dampak pengelolaan keuangan dari tingkat daerah untuk transparansi pengelolaan keuangan di daerah, sehingga digunakanlah analisis regresi yang dibantu dengan alat statistik Social Science Pagcket (SPSS) versi 19, yaitu sebagai berikut:

$Y=a+B_{1} X_{1}+B_{2} X_{2}+B_{3} X_{3}+B_{4} X_{4}+\square$

Keterangan :

$\mathrm{Y} \quad=$ Transparansi pengelolaan keuangan

$\mathrm{a} \quad=$ Intercept

$\mathrm{B} \quad=$ Parameter Regresi

$X_{1}=$ Aspek perencanaan

$\mathrm{X}_{2}=$ Aspek pelaksanaan

$\mathrm{X}_{3} \quad=$ Aspek pelaporan

$\mathrm{X}_{4} \quad=$ Aspek pengawasan

e $\quad=$ Error Term

\section{Pengujian Validitas dan Reabilitas}

Uji Validitas

Kebenaran data yang didapat dengan data yang sesungguhnya terjadi sesuai pada lapangan tempat penelitian yang diteliti (Sugiyono, 2011:121). Alat ukur yang telah disusun untuk mengukur sesuatu yang hendak diukur dengan nyata dilakukan uji validitas untuk mengetahui apakah alat ukur tersebut dapat digunakan. Instrumen Validitas tersebut akan digunakan untuk mengukur objek-objek yang diteliti dengan memperhatikan tingkat kemampuan kuesioner(Sudarmanto, 2005:78). Objek yang akan diteliti dalam penelitian ini adalah sistem pengawasan dan kualitas laporan keuangan. Penelitian ini menggunakan teknik korelasi untuk melakukan pengujian validitas data melalui koefisien korelasi product moment dengan bantuan program SPSS, pada tingkat 
Received: 2021-04-05 Revised: 2021-05-06 Approved: 2021-06-03

signifikansi di bawah 5\%. Menurut Sugiyono (2011:126) acuan untuk menentukan valid atau tidaknya pernyataan bisa dilihat sebagai berikut:

Jika $r$ positif, serta $r \geq 0,30$ maka item pernyataan tersebut valid

Jika $r$ tidak positif, serta $r \leq 0,30$ maka item pernyataan tersebut tidak valid.

Apabila menggunakan cara manual maka nilai korelasi yang diperoleh harus dibandingkan dengan nilai krisis korelasi Product Moment dengan tingkat signifikan 5\%, item pertanyaan dinyatakan valid apabila $r$ hitung $>r$ tabel.

Uji Reliabilitas

Reliabilitas adalah alat ukur yang digunakan dalam penelitian dapat mengukur sesuatu yang diukur secara konsisten dari waktu ke waktu. Syarat kualifikasi instrumen pengukur memiliki syarat yaitu stabil, tetap, atau tidak berubah-ubah (Azwar, 2012: 110). Apabila terdapat kesamaan data dalam waktu yang berbeda maka hasil penelitian bisa dikatakan reliabel (Sugiyono 2011:121). Angket merupakan alat ukur yang memaparkan kevalidan data yang digunakan pada pengujian reliabilitas. Alat ukur yang baik yaitu alat ukur yang stabil dan tetap serta dapat memberikan hasil yang sama atau tidak berubah maka alat ukur data tersebut layak dikatakan reliabilitas(Sudarmanto, 2005:89). Dalam penelitian ini digunakan rumus koefisien Alpha karena skor pada butirbutir instrumen merupakan skor bertingkat yaitu antara 1 sampai 4 atau 1 sampai 5 . Ukuran reliabilitas dianggap handal berdasarkan pada koefisien alpha, maka hasil pengukuran dapat dipertimbangkan sebagai alat ukur dengan tingkat ketelitian dan konsistensi pemikiran yang baik. Menurut (Priyatno, 2010: 26) reliabilitas instrumen yang hasilnya kurang dari 0,6 adalah kurang baik, sedangkan jika hasilnya di atas 0,6 dapat diterima dan hasil yang diatas 0,8 adalah baik.

\section{PEMBAHASAN}

\section{Karakteristik Responden}

Karakteristik responden dalam penelitian ini adalah keadaan pengelola keuangan daerah pada SKPD Kabupaten Lumajang yang terdata. Pejabat pengelola keuangan daerah terpilih secara stratified random sampling di 31 SKPD di lingkungan kerja Pemerintah Daerah pada SKPD Kabupaten Lumajang. Masing-masing SKPD terpilih 2 orang pejabat yang terdiri dari kepala Bagian Keuangan bendaharawan, seluruhnya berjumlah sebanyak 62 pejabat. Pejabat yang terpilih memiliki umur, jenis kelamin, pendidikan dan pengalaman kerja yang berbeda. Karakteristik tersebut membedakan mereka dalam berperilaku, berpersepsi dan memiliki kemampuan dan kemauan kerja yang berbeda. Karakteristik pejabat pengelola keuangan daerah pada SKPD Kabupaten Lumajang dapat dilihat pada Tabel 1.2. 
Received: 2021-04-05 Revised: 2021-05-06 Approved: 2021-06-03

Dari hasil pendataan terhadap 62 pejabat pengelola keuangan daerah pada SKPD Kabupaten Lumajang seperti yang diperlihatkan dalam Tabel 4.1, dapat dijelaskan bahwa sebahagian besar atau $46,8 \%$ dari jumlah pejabat pengelola keuangan daerah yang terdata tersebut berumur antara 36-40 tahun. Ada 8,1\% dari jumlah pejabat yang terdata dengan umur lebih dari 50 tahun dan 14,5\% berumur lebih muda yaitu antara 31-35 tahun. Selebihnya 21,0\% dan 9,7\% dari jumlah pejabat pengelola keuangan daerah yang terdata pada pada SKPD Kabupaten Lumajang berumur antara 41-45 tahun dan 4650 tahun.

Tabel 1.2

Karakteristik Responden/ Pejabat Pengelola Keuangan Daerah pada SKPD Kabupaten Lumajang

\begin{tabular}{cccc}
\hline \multirow{4}{*}{ Karakteristik } & Frekuensi (n) & Persentase (\%) \\
\hline \multirow{4}{*}{ Umur } & $31-35$ & 9 & 14,5 \\
& $36-40$ & 29 & 46,8 \\
& $41-45$ & 13 & 21,0 \\
& $46-50$ & 6 & 9,7 \\
& $>50$ & 5 & 8,1 \\
& Total & 62 & 100,0 \\
\multirow{5}{*}{ Status } & DIII & 3 & 4,8 \\
& S1 & 51 & 82,3 \\
& S2 & 8 & 12,9 \\
& Total & 62 & 100,0 \\
Pendapatan & Laki-laki & 51 & 82,3 \\
& Perempuan & 11 & 17,7 \\
& Total & 62 & 100,0 \\
& 5-10 tahun & 9 & 14,5 \\
& $11-20$ tahun & 36 & 58,1 \\
& $>20$ tahun & 17 & 27,4 \\
& Total & 62 & 100,0 \\
\hline
\end{tabular}

Sumber :Data Primer (diolah), 2021

Dilihat dari pendidikan terakhir, sebahagian besar atau 82,3\% dari jumlah pejabat pengelola keuangan daerah yang terdata pada SKPD Kabupaten Lumajang adalah mereka dengan tingkat pendidikan S1. Ada 12,9\% dari jumlah pejabat yang terdata dengan tingkat pendidikan S2. Selebihnya 4,8\% dari jumlah pejabat dengan tingkat pendidikan DIII. Pejabat pengelola keuangan daerah yang terdata pada SKPD Kabupaten Lumajang sebahagian besar atau $82.3 \%$ adalah laki-laki, hanya $17,7 \%$ dari jumlah pejabat dengan jenis kelamin perempuan.

Dilihat dari pengalaman kerja, sebahagian besar atau 58,1\% dari jumlah pejabat pengelola keuangan daerah pada SKPD Kabupaten Lumajang telah bekerja selama 11-20 tahun. Ada 27,4\% dari jumlah pejabat dengan masa kerja lebih dari 20 tahun. 
Received: 2021-04-05 Revised: 2021-05-06 Approved: 2021-06-03

Selebihnya 14,5\% dari jumlah pejabat yang terdata pada pada SKPD Kabupaten Lumajang dengan masa kerja antara 5-10 tahun.

\section{Variabel Aspek Perencanaan}

Tabel. 1.3

Aspek Perencanaan Keuangan Daerah pada SKPD Kabupaten Lumajang.

\begin{tabular}{|c|c|c|c|c|c|c|c|c|c|c|c|c|}
\hline \multirow[t]{2}{*}{ No. } & \multirow[t]{2}{*}{ Indikator } & \multicolumn{2}{|c|}{$\begin{array}{l}\text { Sgt Tdk } \\
\text { Setuju }\end{array}$} & \multicolumn{2}{|c|}{$\begin{array}{c}\text { Tdk } \\
\text { Setuju }\end{array}$} & \multicolumn{2}{|c|}{$\begin{array}{l}\text { Kurang } \\
\text { Setuju }\end{array}$} & \multicolumn{2}{|c|}{ Setuju } & \multicolumn{2}{|c|}{$\begin{array}{c}\text { Sgt } \\
\text { Setuju }\end{array}$} & \multirow{2}{*}{ Mean } \\
\hline & & $\mathrm{Fr}$ & $\%$ & $\mathrm{Fr}$ & $\%$ & $\mathrm{Fr}$ & $\%$ & $\mathrm{Fr}$ & $\%$ & $\mathrm{Fr}$ & $\%$ & \\
\hline 1. & $\begin{array}{l}\text { Rencana program kerja kegiatan } \\
\text { SKPD jelas dalam arti berpihak pada } \\
\text { masyarakat. }\end{array}$ & 0 & 0,0 & 0 & 0,0 & 26 & 41,9 & 27 & 43,5 & 9 & 14,5 & 3.725 \\
\hline 2. & $\begin{array}{l}\text { SKPD selalu memiliki target kinerja } \\
\text { yang bermanfaat bagi } \\
\text { masyarakat }\end{array}$ & 0 & 0,0 & 0 & 0,0 & 36 & 58,1 & 16 & 25,8 & 10 & 16,1 & 3.580 \\
\hline 3. & $\begin{array}{l}\text { SKPD selalu mentetapkan program } \\
\text { kerja yang prioritas berdasarkan } \\
\text { alokasi anggaran yang } \\
\text { semakin terbatas. }\end{array}$ & 0 & 0,0 & 0 & 0,0 & 25 & 40,3 & 34 & 54,8 & 3 & 4,8 & 3.645 \\
\hline 4. & $\begin{array}{l}\text { SKPD menetapkan rencana } \\
\text { anggaran secara rasional berdasarkan } \\
\text { standar harga. }\end{array}$ & 0 & 0,0 & 0 & 0,0 & 162 & 25,8 & 26 & 41,9 & 20 & 32,3 & 4.064 \\
\hline & Rerata & & & & & & & 753 & & & & \\
\hline
\end{tabular}
Sumber :Data Primer (diolah),2021

Tabel 1.3 menjelaskan aspek perencanaan pada SKPD Kabupaten Lumajang sudah relatif baik dengan nilai jawaban rata-rata 3,753 satuan. Nilai tersebut mendekati 4 (skor untuk pilihan jawaban setuju). Kondisi ini menandakan sebahagian besar dari jumlah pejabat pengelola keuangan daerah yang terdata pada SKPD Kabupaten Lumajang menjawab setuju untuk sejumlah pertanyaan yang berkaitan dengan aspek perencanaan tersebut. Kalaupun ada dari mereka yang memilih alternatif pilihan jawaban tidak setuju, kurang setuju dan sangat setuju hanya sebahagian kecil.

Dari 5 (lima) indikator pertanyaan yang digunakan untuk menilai aspek perencanaan pada SKPD Kabupaten Lumajang. standard harga satuan yang rasional menjadi indikator aspek perencanaan yang terbaik dengan nilai jawaban tertinggi yaitu sebesar 4,064. Nilai tersebut lebih tinggi dari nilai indikator lainnya dan mendekati 4 (skor untuk pilihan jawaban setuju). Kondisi ini menandakan sebahagian besar dari jumlah pejabat pengelola keuangan daerah pada SKPD Kabupaten Lumajang menjawab setuju jika SKPD menetapkan rencana anggaran secara rasional berdasarkan standar harga.

Sementara penetapan prioritas kegiatan dan perhitungan beban kerja, serta menjadi indikator aspek perencanaan dengan nilai jawaban terendah yaitu 3.645. Nilai tersebut mendekati 3 (skor untuk pilihan jawaban kurang setuju). Kondisi ini menandakan sebahagian besar dari jumlah pejabat pengelolaan keuangan daerah pada SKPD 
Received: 2021-04-05 Revised: 2021-05-06 Approved: 2021-06-03

Kabupaten Lumajang menjawab kurang setuju jika SKPD selalu menetapkan program kerja yang prioritas berdasarkan alokasi anggaran yang semakin terbatas.

\section{Variabel Aspek Penatausahaan}

Tabel. 1.4

Aspek Penatausahaan Keuangan Daerah pada SKPD Kabupaten Lumajang

\begin{tabular}{|c|c|c|c|c|c|c|c|c|c|c|c|c|}
\hline \multirow[t]{2}{*}{ No. } & \multirow[t]{2}{*}{ Indikator } & \multirow{2}{*}{\multicolumn{2}{|c|}{$\begin{array}{l}\text { Sgt Tdk } \\
\text { Setuju } \\
\text { Fr } \%\end{array}$}} & \multicolumn{2}{|c|}{$\begin{array}{l}\text { Tdk } \\
\text { Setuju }\end{array}$} & \multicolumn{2}{|c|}{$\begin{array}{l}\text { Kurang } \\
\text { Setuju }\end{array}$} & \multicolumn{2}{|c|}{ Setuju } & \multicolumn{2}{|c|}{$\begin{array}{c}\text { Sgt } \\
\text { Setuju }\end{array}$} & \multirow{2}{*}{ Mean } \\
\hline & & & & $\mathrm{Fr}$ & $\%$ & $\mathrm{Fr}$ & $\%$ & $\mathrm{Fr}$ & $\%$ & $\mathrm{Fr}$ & $\%$ & \\
\hline 1. & $\begin{array}{l}\text { SKPD selalu mencatat atas setiap bukti } \\
\text { pengeluaran dan penerimaan kas dengan } \\
\text { metode akuntansi yang } \\
\text { konsisten. }\end{array}$ & 0 & 0,0 & 0 & 0,0 & 8 & 12,9 & 41 & 66,1 & 13 & 21,0 & 4,080 \\
\hline 2. & $\begin{array}{l}\text { SKPD selalu melakukan jurnal penyesuaian } \\
\text { akhir tahun yang } \\
\text { belum relevan. }\end{array}$ & 0 & 0,0 & 0 & 0,0 & 25 & 40,3 & 29 & 46,8 & 8 & 12,9 & 3,725 \\
\hline & $\begin{array}{l}\text { SKPD selalu mengungkapkan seluruh } \\
\text { transaksi penggunaan }\end{array}$ & & & & & & & & & & & \\
\hline 3. & $\begin{array}{l}\text { anggaran dalam laporan keuangan yang } \\
\text { jelas, netral dan tepat waktu. }\end{array}$ & 0 & 0,0 & 3 & 4,8 & 36 & 58,1 & 22 & 35,5 & 1 & 1,6 & 3,338 \\
\hline
\end{tabular}

Rerata Sumber :Data Primer (diolah), 2021

Tabel 1.4 menjelaskan pelaksanaan dan penatausahaan keuangan daerah pada SKPD Kabupaten Lumajang sudah relatif baik dengan nilai jawaban rata-rata 3,714 satuan. Nilai tersebut mendekati 4 (skor untuk pilihan jawaban setuju). Kondisi ini menandakan sebahagian besar dari jumlah pejabat pengelola keuangan daerah yang ter data pada SKPD Kabupaten Lumajang menjawab setuju untuk sejumlah pertanyaan yang berkaitan dengan aspek pelaksanaan dan penatausahaan keuangan daerah tersebut. Kalaupun ada dari mereka yang memilih alternatif pilihan jawaban tidak setuju, kurang setuju dan sangat setuju hanya sebahagian kecil.

Dari 3 (tiga) indikator pertanyaan yang digunakan untuk menilai aspek pelaksanaan dan penatausahaan keuangan daerah pada SKPD Kabupaten Lumajang, proses pencatatan yang handal menjadi indikator aspek pelaksanaan dan penatausahaan keuangan daerah yang terbaik dengan nilai jawaban tertinggi yaitu sebesar 4,080. Nilai tersebut lebih tinggi dari nilai indikator lainnya dan mendekati 4 (skor untuk pilihan jawaban setuju). Kondisi ini menandakan sebahagian besar dari jumlah pejabat pengelola keuangan daerah pada SKPD Kabupaten Lumajang menjawab setuju jika SKPD selalu mencatat atas setiap bukti pengeluaran dan penerimaan kas dengan metode akuntansi yang konsisten

Sementara kegiatan pelaporan masih menjadi indikator aspek pelaksanaan dan penatausahaan keuangan daerah dengan nilai jawaban terendah yaitu 3.338. Nilai 
Received: 2021-04-05 Revised: 2021-05-06 Approved: 2021-06-03

tersebut mendekati 3 (skor untuk pilihan jawaban kurang setuju). Kondisi ini menandakan sebahagian besar dari jumlah pejabat pengelolaan keuangan daerah pada SKPD Kabupaten Lumajang menjawab kurang setuju jika SKPD selalu mengungkapkan seluruh transaksi penggunaan anggaran dalam laporan keuangan yang jelas, netral dan tepat waktu.

Variabel Aspek Pelaporan

Tabel. 1.5

Aspek Pelaporan Keuangan Daerah pada SKPD Kabupaten Lumajang

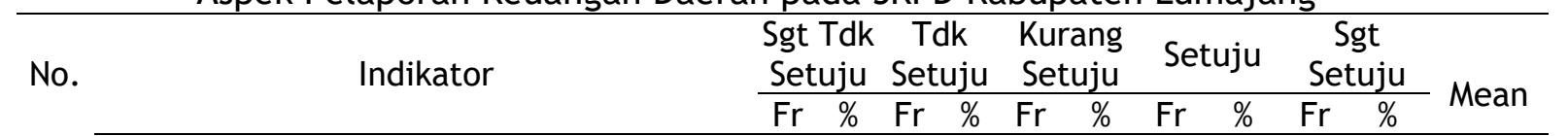

1

Laporan keuangan sampaikan tepat waktu

dan sesuai dengan

prosedur.

$\begin{array}{lllllllllll}0 & 0,0 & 0 & 0,0 & 27 & 43,5 & 25 & 40,3 & 10 & 16,1 & 3.725\end{array}$

Laporan keuangan menyajikan seluruh pos penerimaan dan pengeluaran secara rinci

2 serta dilengkapi dengan informasi pendukung.

Pos-pos keuangan yang disajikan dalam laporan keuangan merupakan perihal

3 tentang transaksi keuangan sesungguhnya.

Penyusunan laporan keuangan tidak berpihak pada kepentingan kelompok dan unit kerja namun untuk meningkatkan penyelengaraan pemerintah disektor publik

4 secara luas dan $\begin{array}{lllllllllll}0 & 0,0 & 4 & 6,5 & 29 & 46,8 & 23 & 37,1 & 6 & 9,7 & 3.5\end{array}$ merata

Syarat penyajian pos-pos laporan keuangan sesuai dengan prosedur dan ketentuan yang

5. berlaku sehingga tidak berbeda dengan laporan keungan pada instansi lain.

Struktur dan pos-pos keuangan yang

6. disajikan dalam laporan

keuanga mudah dipahami dan dimengerti.

$\begin{array}{lllllllllll}0 & 0,0 & 2 & 3,2 & 34 & 54,8 & 22 & 35,5 & 4 & 6,5 & 3.451\end{array}$

Rerata 3,609 Sumber :Data Primer (diolah), 2021

Tabel 1.5 menjelaskan aspek pelaporan keuangan daerah pada SKPD Kabupaten Lumajang sudah relatif baik dengan nilai jawaban rata-rata 3,609 satuan. Nilai tersebut mendekati 4 (skor untuk pilihan jawaban setuju). Kondisi ini menandakan sebahagian besar dari jumlah pejabat pengelola keuangan daerah yang ter data pada SKPD 
Received: 2021-04-05 Revised: 2021-05-06 Approved: 2021-06-03

Kabupaten Lumajang menjawab setuju untuk sejumlah pertanyaan yang berkaitan dengan aspek pelaporan tersebut. Kalaupun ada dari mereka yang memilih alternatif pilihan jawaban tidak setuju, kurang setuju dan sangat setuju hanya sebahagian kecil.

Dari 6 (enam) indikator pertanyaan yang digunakan untuk menilai aspek pelaporan pada SKPD Kabupaten Lumajang. laporan disampaikan tepat waktu menjadi indikator aspek pelaporan yang terbaik dengan nilai jawaban tertinggi yaitu sebesar 3,725. Nilai tersebut lebih tinggi dari nilai indikator lainnya dan mendekati 4 (skor untuk pilihan jawaban setuju). Kondisi ini menandakan sebahagian besar dari jumlah pejabat pengelola keuangan daerah pada SKPD Kabupaten Lumajang menjawab setuju jika laporan keuangan sampaikan tepat waktu dan sesuai dengan prosedur.

Sementara laporan keuangan dapat dipahami dengan mudah menjadi indikator aspek pelaporan dengan nilai jawaban terendah yaitu 3.451. Nilai tersebut mendekati 3 (skor untuk pilihan jawaban kurang setuju). Kondisi ini menandakan sebahagian besar dari jumlah pejabat pengelolaan keuangan daerah pada SKPD Kabupaten Lumajang menjawab kurang setuju jika struktur dan pos-pos keuangan yang disajikan dalam laporan keuangan mudah dipahami dan dimengerti.

\section{Variabel Aspek Pengawasan}

Tabel. 1.6

Aspek Pengawasan Keuangan Daerah pada SKPD Kabupaten Lumajang.

\begin{tabular}{|c|c|c|c|c|c|c|c|c|c|c|c|c|}
\hline \multirow[t]{2}{*}{ No. } & \multirow[t]{2}{*}{ Indikator } & \multicolumn{2}{|c|}{$\begin{array}{l}\text { Sgt Tdk } \\
\text { Setuju }\end{array}$} & \multicolumn{2}{|c|}{$\begin{array}{l}\text { Tdk } \\
\text { Setuju }\end{array}$} & \multicolumn{2}{|c|}{$\begin{array}{l}\text { Kurang } \\
\text { Setuju }\end{array}$} & \multicolumn{2}{|c|}{ Setuju } & \multicolumn{2}{|c|}{$\begin{array}{c}\text { Sgt } \\
\text { Setuju }\end{array}$} & \multirow{2}{*}{ Mean } \\
\hline & & $\overline{\mathrm{Fr}}$ & $\%$ & $\mathrm{Fr}$ & $\%$ & $\mathrm{Fr}$ & $\%$ & $\mathrm{Fr}$ & $\%$ & $\mathrm{Fr}$ & $\%$ & \\
\hline 1. & $\begin{array}{l}\text { Transaksi dan bukti-bukti penggunaan } \\
\text { anggaran diperiksa kebenarannya. } \\
\text { Penyelenggaraan akuntansi dan penyajian }\end{array}$ & 0 & 0,0 & 0 & 0,0 & 26 & 41,9 & 31 & 50,0 & 5 & 8,1 & 3.661 \\
\hline 2. & $\begin{array}{l}\text { laporan ditelaah secara } \\
\text { langsung. }\end{array}$ & 0 & 0,0 & 0 & 0,0 & 26 & 41,9 & 30 & 48,4 & 6 & 9,7 & 3.677 \\
\hline 3. & $\begin{array}{l}\text { Seluruh transaksi penggunaan uang publik } \\
\text { di evaluasi secara } \\
\text { berkala. }\end{array}$ & 0 & 0,0 & 4 & 6,5 & 34 & 54,8 & 22 & 35,5 & 2 & 3,2 & 3.354 \\
\hline 4. & $\begin{array}{l}\text { Penyelenggaraan anggaran publik dan } \\
\text { penerapan akuntansi dilakukan } \\
\text { pemantauan setiap saat }\end{array}$ & 0 & 0,0 & 6 & 9,7 & 37 & 59,7 & 19 & 30,6 & & 0,0 & 3.209 \\
\hline 5. & $\begin{array}{l}\text { Pelaksanaan aspek anggaran publik selalu } \\
\text { diarahkan dan dikoordinasi oleh pimpinan } \\
\text { unit kerja }\end{array}$ & 0 & 0,0 & 1 & 1,6 & 30 & $\begin{array}{r}48,4 \\
3,4\end{array}$ & $\begin{array}{r}27 \\
489\end{array}$ & 43,5 & 4 & 6,5 & 3.548 \\
\hline
\end{tabular}

Sumber: Data Primer (diolah), 2021

Tabel 1.6 menjelaskan aspek pengawasan keuangan daerah pada SKPD Kabupaten Lumajang masih relatif kurang baik dengan nilai jawaban rata-rata 3,489 satuan. Nilai tersebut mendekati 3 (skor untuk pilihan jawaban kurang setuju). Kondisi ini 
Received: 2021-04-05 Revised: 2021-05-06 Approved: 2021-06-03

menandakan sebahagian besar dari jumlah pejabat pengelola keuangan daerah yang ter data pada SKPD Kabupaten Lumajang menjawab kurang setuju untuk sejumlah pertanyaan yang berkaitan dengan aspek pengawasan tersebut. Kalaupun ada dari mereka yang memilih alternatif pilihan jawaban tidak setuju, setuju dan sangat setuju hanya sebahagian kecil.

Dari 5 (lima) indikator pertanyaan yang digunakan untuk menilai aspek pengawasan keuangan daerah pada SKPD Kabupaten Lumajang. kegiatan reviu menjadi indikator aspek pengawasan yang terbaik dengan nilai jawaban tertinggi yaitu sebesar 3,677. Nilai tersebut lebih tinggi dari nilai indikator lainnya dan mendekati 4 (skor untuk pilihan jawaban setuju). Kondisi ini menandakan sebahagian besar dari jumlah pejabat pengelola keuangan daerah pada SKPD Kabupaten Lumajang menjawab setuju jika penyelenggaraan akuntansi dan penyajian laporan ditelaah secara langsung.

Sementara pemantauan menjadi indikator aspek pengawasan dengan nilai jawaban terendah yaitu 3.209. Nilai tersebut mendekati 3 (skor untuk pilihan jawaban kurang setuju). Kondisi ini menandakan sebahagian besar dari jumlah pejabat pengelolaan keuangan daerah pada SKPD Kabupaten Lumajang menjawab kurang setuju jika Penyelenggaraan anggaran publik dan penerapan akuntansi dilakukan pemantauan setiap saat.

\section{Transparansi Pengelolaan Keuangan Daerah}

Tabel. 1.7

Gambaran Transparansi Pengelolaan Keuangan Daerah pada SKPD Kabupaten Lumajang.

No. Indikator

\begin{tabular}{|c|c|c|c|c|}
\hline $\begin{array}{l}\text { Sgt Tdl } \\
\text { Setuju }\end{array}$ & $\begin{array}{c}\text { Tdk } \\
\text { Setuju }\end{array}$ & $\begin{array}{l}\text { Kurang } \\
\text { Setuju }\end{array}$ & Setuju & $\begin{array}{l}\text { Sgt } \\
\text { Setuju }\end{array}$ \\
\hline Fr $\%$ & $\mathrm{Fr}$ & Fr $\%$ & $\mathrm{Fr}$ & $\mathrm{Fr}$ \\
\hline
\end{tabular}

SKPD selalu mempublikasikan tentang pelaksanaan, kendala dan kesiapan

1. penyusunan program

$\begin{array}{lllllllllll}0 & 0,0 & 0 & 0,0 & 26 & 41,9 & 34 & 54,8 & 2 & 3,2 & 3.612\end{array}$ kegiatan.

Data dan informasi tentang program kegiatan SKPD dapat diakses dengan mudah

2. melalui $\begin{array}{lllllllllll}0 & 0,0 & 0 & 0,0 & 22 & 35,5 & 33 & 53,2 & 7 & 11,3 & 3.758\end{array}$ berbagai media.

Data dan informasi yang di publikasi SKPD

3. di berbagai media informasi selalu update.

Masyarakat ikut serta memberikan ide dan saran untuk perbaikan program kerja SKPD

4. melalui kotak $\begin{array}{lllllllllll}0 & 0,0 & 0 & 0,0 & 46 & 74,2 & 16 & 25,8 & 0 & 0,0 & 3.258\end{array}$ saran 
Received: 2021-04-05 Revised: 2021-05-06 Approved: 2021-06-03

SKPD selalu menyampaikan informasi pertanggungjawaban kepada publik baik

5. secara tertulis maupun melalui Aparatur Pengawasan.

$\begin{array}{lllllllllll}0 & 0,0 & 0 & 0,0 & 28 & 45,2 & 34 & 54,8 & 0 & 0,0 & 3.548\end{array}$

Rerata 3,528

Sumber: Data Primer (diolah), 2021

Tabel 1.7 menjelaskan transparansi pengelolaan keuangan daerah pada SKPD Kabupaten Lumajang masih relatif kurang baik dengan nilai jawaban rata-rata 3,528 satuan. Nilai tersebut mendekati 4 (skor untuk pilihan jawaban setuju). Kondisi ini menandakan sebahagian besar dari jumlah pejabat pengelola keuangan daerah yang terdata pada SKPD Kabupaten Lumajang menjawab setuju untuk sejumlah pertanyaan yang berkaitan dengan transparansi pengelolaan keuangan daerah tersebut. Kalaupun ada dari mereka yang memilih alternatif pilihan jawaban tidak setuju, kurang setuju dan sangat setuju hanya sebahagian kecil.

Dari 5 (lima) indikator pertanyaan yang digunakan untuk menilai transparansi pengelolaan keuangan daerah pada SKPD Kabupaten Lumajang. Tujuan dan manfaat akhir telah tercapai menjadi indikator transparansi pengelolaan keuangan daerah yang terbaik dengan nilai jawaban tertinggi yaitu sebesar 3,758. Nilai tersebut lebih tinggi dari nilai indikator lainnya dan mendekati 4 (skor untuk pilihan jawaban setuju). Kondisi ini menandakan sebahagian besar dari jumlah pejabat pengelola keuangan daerah pada SKPD Kabupaten Lumajang menjawab setuju jika Tujuan dan manfaat akhir yang direncanakan SKPD telah dapat tercapai.

Sementara Manfaat program kerja dapat tercapai dengan biaya yang cukup rendah (efektivitas biaya) menjadi indikator transparansi pengelolaan keuangan daerah dengan nilai jawaban terendah yaitu 3.258. Nilai tersebut mendekati 3 (skor untuk pilihan jawaban kurang setuju). Kondisi ini menandakan sebahagian besar dari jumlah pejabat pengelolaan keuangan daerah pada SKPD Kabupaten Lumajang menjawab kurang setuju jika manfaat program kerja dapat tercapai dengan biaya yang cukup rendah (efektivitas biaya).

\section{Uji Validitas}

Sebelum dianalisis lebih lanjut dalam model analisis regresi linier berganda, maka terlebih dahulu dilakukan pengujian validitas dengan menggunakan analisis korelasi person. Uji ini dimaksud untuk mendapatkan data yang sebenarnya sesuai dengan kondisi dan kenyataan yang terjadi atau sebagaimana yang diharapkan. Kuesioner harus bebas dari kesalahan dalam arti kuesioner yang digunakan harus dapat berfungsi memberikan informasi yang relevan mengenai aktivitas dan perilaku yang diteliti Uji 
Received: 2021-04-05 Revised: 2021-05-06 Approved: 2021-06-03

validitas dilakukan dengan menggunakan uji Pearson Product-Moment Coeffisient of Corelation. Uji Pearson Product-Moment menghasilkan nilai dari 0 sampai dengan 1 sebagai bentuk hubungan yang sangat kuat. yang menggambarkan hubungan skor item pertanyaan dengan skor data yang digunakan secara keseluruhan. Kemudian nilai korelasi tersebut hasil perhitungan dibandingkan dengan nilai kritis korelasi product moment pada tingkat signifikansi $5 \%$ dan sebesar 62 sampel yaitu sebesar 0,266 . Hasil uji validitas dapat dilihat pada Tabel 1.7

Tabel 1.7 Hasil Uji Validitas

\begin{tabular}{ccccc}
\hline & Indikator & $\begin{array}{c}\text { Koefisien } \\
\text { Korelasi }\end{array}$ & $\begin{array}{c}\text { Nilai Kritis } r \\
\mathrm{~N}=62\end{array}$ & Keterangan \\
\hline B1 & & 0,787 & 0,266 & Valid \\
B2 & Perencanaan & 0,862 & 0,266 & Valid \\
B3 & & 0,785 & 0,266 & Valid \\
B4 & & 0,915 & 0,266 & Valid \\
C1 & Pelaksanaan dan & 0,702 & 0,266 & Valid \\
C2 & penatausahaan & 0,753 & 0,266 & Valid \\
C3 & & 0,654 & 0,266 & Valid \\
D1 & & 0,695 & 0,266 & Valid \\
D2 & & 0,442 & 0,266 & Valid \\
D3 & Pelaporan dan & 0,751 & 0,266 & Valid \\
D4 & pertanggungjawaban & 0,788 & 0,266 & Valid \\
D5 & & 0,673 & 0,266 & Valid \\
D6 & & 0,701 & 0,266 & Valid \\
E1 & & 0,620 & 0,266 & Valid \\
E2 & & 0,894 & 0,266 & Valid \\
E3 & & 0,911 & 0,266 & Valid \\
E4 & Pengawasan & 0,869 & 0,266 & Valid \\
E5 & & 0,738 & 0,266 & Valid \\
F1 & & 0,774 & 0,266 & Valid \\
F2 & & 0,782 & 0,266 & Valid \\
F3 & Efektivitas penganggaran & 0,876 & 0,266 & Valid \\
F4 & & 0,807 & 0,266 & Valid \\
F5 & & 0,786 & 0,266 & Valid \\
\hline
\end{tabular}

Sumber :Data Primer (diolah), 2021

Seluruh nilai atribut pertanyaan yang membentuk variabel bebas meliputi perencanaan $\left(\mathrm{X}_{1}\right)$, pelaksanaan dan penatausahaan $\left(\mathrm{X}_{2}\right)$, pelaporan dan pertanggungjawaban $\left(\mathrm{X}_{3}\right)$, pengawasan $\left(\mathrm{X}_{4}\right)$, dan transparansi pengelolaan keuangan daerah $(\mathrm{Y})$ dinyatakan valid atau dapat dianalisis lebih lanjut dalam model analisis regresi karena nilai koefisien korelasi dari masing-masing nilai atribut yang membentuk variabel lebih besar dari nilai kritis product-moment pada level of significant $5 \%(0,266)$.

\section{Hasil Pengujian Reliabilitas}

Uji reliabilitas dilakukan untuk mengetahui tingkat konsistensi alat ukur dalam menghasilkan data yang dapat dipercaya. Maka dilakukan pengukuran secara aspek tis 
Received: 2021-04-05 Revised: 2021-05-06

Approved: 2021-06-03

terhadap instrumen penelitian yaitu angket atau dalam bahasa asing dikenal dengan kuesioner. Uji reliabilitas atau kepercayaan ini dilakukan untuk mengetahui tingkat konsistensi jawaban yang diberikan responden. Semakin konsisten jawaban yang diberikan dalam arti adanya kesamaan pandangan dan pendapat maka akan semakin terpercaya alat ukur yang digunakan tersebut.

Pengujian reliabilitas dalam penelitian dilakukan dengan teknik belahan data dengan dukungan rumus koefisien alpha dari Cronbach atau biasa disebut dengan Cronbach Coefficient Alpha. Ukuran reliabilitas dianggap handal berdasarkan pada koefesien alpha 0,60 (Priyanto, 2012: 26). Jika derajat Perencanaan data lebih besar dari koefesien alpha (a), maka hasil pengukuran dapat dipertimbangkan sebagai alat ukur dengan tingkat ketelitian dan konsistensi pemikiran yang baik. Hasil uji Perencanaan dapat dilihat pada Tabel 1.8

Tabel. 1.8 Hasil Uji Reliabilitas

\begin{tabular}{llcccc}
\hline \multirow{2}{*}{ No } & \multicolumn{1}{c}{ Variabel } & $\begin{array}{c}\text { Jumlah } \\
\text { Atribut }\end{array}$ & $\begin{array}{c}\text { Item } \\
\text { Pertanyaan }\end{array}$ & $\begin{array}{c}\text { Nilai } \\
\text { Cobranc Alpha }\end{array}$ & Keterangan \\
\hline 1 & Aspek perencanaan $\left(\mathrm{X}_{1}\right)$ & 5 & $\mathrm{C} 1 \mathrm{~s} / \mathrm{d} \mathrm{C4}$ & 0,742 & Handal \\
2 & Aspek penatausahaan $\left(\mathrm{X}_{2}\right)$ & 5 & D1 s/d D3 & 0,763 & Handal \\
3 & Aspek Pelaporan $\left(\mathrm{X}_{3}\right)$ & 5 & E1 s/d E6 & 0,761 & Handal \\
4 & Aspek Pengawasan $\left(\mathrm{X}_{4}\right)$ & 5 & $\mathrm{~F} 1 \mathrm{~s} / \mathrm{d} \mathrm{F5}$ & 0,778 & Handal \\
& $\begin{array}{l}\text { Transparansi pengelolaan } \\
\text { keuangan daerah }(\mathrm{Y})\end{array}$ & 5 & $\mathrm{~B} 1 \mathrm{~s} / \mathrm{d} \mathrm{B5}$ & 0,818 & Handal \\
\hline
\end{tabular}

Sumber: Data Primer (diolah), 2021

Hasil uji reliabilitas terhadap variabel perencanaan $\left(X_{1}\right)$, pelaksanaan dan penatausahaan $\left(X_{2}\right)$, pelaporan dan pertanggungjawaban $\left(X_{3}\right)$, pengawasan $\left(X_{4}\right)$, dan transparansi pengelolaan keuangan daerah(Y) pada SKPD Kabupaten Lumajang diperoleh nilai Alpha masing-masing lebih besar dari standar alfa 0,60. Dengan demikian variabel penelitian yang digunakan tersebut telah dapat dipercaya atau telah memenuhi kredibilitas Cronbach's Alpha (Perencanaan) dengan nilai Alpha melebihi 60\% (Priyanto, 2012: 26). Dengan demikian ke lima variabel dapat dianalisis lebih lanjut dalam model analisis regresi.

\section{Hasil Koefisien Regresi Linier Berganda}

Untuk mengetahui pengaruh aspek pengelolaan keuangan daerah terhadap transparansi pengelolaan keuangan daerah pada SKPD Kabupaten Lumajang maka dioperasionalkan 5 (lima) variabel yang terdiri dari satu variabel terikat yaitu transparansi pengelolaan keuangan daerah $(\mathrm{Y})$ dan 4 (empat) variabel bebas yang terdiri dari perencanaan $\left(\mathrm{X}_{1}\right)$, pelaksanaan dan penatausahaan $\left(X_{2}\right)$, pelaporan dan pertanggungjawaban $\left(X_{3}\right)$ dan 
Received: 2021-04-05 Revised: 2021-05-06 Approved: 2021-06-03

pengawasan $\left(\mathrm{X}_{4}\right)$. Pengaruh tersebut dalam model analisis ini dapat dibuktikan melalui formula regresi berganda (multiple regression).

Formulasi regresi linier berganda bertujuan untuk memprediksi sejauh mana tingkat kenaikan skala likert dari 4 (empat) variabel bebas terhadap kenaikan skala variabel terikat pada tingkat kesalahan tertentu (signifikan) atau dimana pengaruh antar variabel tersebut benar-benar nyata (signifikan). Hasil output SPSS regresi linier berganda pengaruh variabel bebas dan terikat dapat dilihat pada Tabel 1.9

Tabel 1.9

Hasil Analisis Regresi

\begin{tabular}{lllll}
\hline Model & & \multicolumn{2}{l}{$\begin{array}{l}\text { Unstandardized } \\
\text { Coefficients }\end{array}$} & $\begin{array}{l}\text { Standardized } \\
\text { Coefficients } \\
\text { Beta }\end{array}$ \\
& B & Std. Error & Beta \\
\hline $1 \quad$ (Constant) & 0,331 & 0,287 & \\
& $\begin{array}{l}\text { Perencanaan } \\
\text { Pelaksanaan dan penatausahaan }\end{array}$ & 0,141 & 0,062 & 0,185 \\
Pelaporan dan & 0,314 & 0,068 & 0,126 \\
pertanggungjawaban & & 0,083 & 0,375 \\
Pengawasan & 0,338 & 0,093 & 0,389 \\
\hline
\end{tabular}

Sumber :Data Primer (diolah), 2021

$$
Y=0,331+0,141 X_{1}+0,096 X_{2}+0,314 X_{3}+0,338 X_{4}+e
$$

Nilai konstanta transparansi pengelolaan keuangan daerah adalah sebesar 0,331. Nilai tersebut menjelaskan bahwa jika diasumsikan variabel perencanaan, pelaksanaan dan penatausahaan, pelaporan dan pertanggungjawaban serta variabel pengawasan tidak mengalami perubahan, maka transparansi pengelolaan keuangan daerah pada SKPD Kabupaten Lumajang secara konstan adalah sebesar 0,331 satuan.

Koefisien regresi pengaruh aspek perencanaan adalah sebesar $b_{1}=0,141$. Nilai tersebut menjelaskan setiap meningkatnya aspek perencanaan 1 satuan maka dapat meningkatkan transparansi pengelolaan keuangan daerah pada SKPD Kabupaten Lumajang sebesar 0,141 satuan.

Koefisien regresi pengaruh aspek pelaksanaan dan penatausahaan adalah sebesar $b_{2}=$ 0,096. Nilai tersebut menjelaskan setiap meningkatnya sistem pelaksanaan dan penatausahaan keuangan daerah 1 satuan maka dapat meningkatkan transparansi pengelolaan keuangan daerah pada SKPD Kabupaten Lumajang sebesar 0,096 satuan.

Koefisien regresi pengaruh aspek pelaporan dan pertanggungjawaban adalah sebesar $b_{3}$ $=0,404$. Nilai tersebut menjelaskan setiap meningkatnya aspek pelaporan dan pertanggungjawaban sebesar 1 satuan maka dapat meningkatkan transparansi pengelolaan keuangan daerah pada SKPD Kabupaten Lumajang sebesar 0,404 satuan. 
Received: 2021-04-05 Revised: 2021-05-06

Approved: 2021-06-03

Koefisien regresi pengaruh aspek pengawasan adalah sebesar $b_{4}=0,338$. Nilai tersebut menjelaskan setiap meningkatnya aspek pengawasan sebesar 1 satuan maka akan dapat meningkatkan transparansi pengelolaan keuangan daerah pada SKPD Kabupaten Lumajang sebesar 0,338 satuan.

\section{Koefisien Korelasi dan Determinasi}

Untuk menganalisis hubungan antara variabel penelitian juga digunakan analisis formulasi korelasi dan determinasi. Korelasi ( $r$ ) positif kuat apabila hasil korelasi mendekati 1 atau sama dengan 1. Korelasi negatif kuat apabila hasil korelasi mendekati -1 atau sama dengan -1. Tidak ada korelasi apabila hasil korelasi mendekati 0 atau sama dengan 0 . Sementara kolerasi determinasi $\left(r^{2}\right)$ menjelaskan sejauh mana kontribusi hubungan satu variabel dengan variabel lainnya. Hasil analisis korelasi dan determinasi dapat dilihat pada Tabel 1.10:

Tabel 1.10

Hasil Analisis Korelasi dan Diterminasi

\begin{tabular}{|l|l|ll|}
\hline Model & $\mathrm{R}$ & $\mathrm{R}$ Square & Adjusted R Square \\
\hline 1 & 0,861 & 0,741 & 0,720 \\
\hline \multicolumn{4}{|c|}{ Sumber:Data Primer (diolah), 2021}
\end{tabular}

Koefisien korelasi sebesar $r=0,861$ menjelaskan terdapat hubungan positif secara simultan antara aspek perencanaan $\left(X_{1}\right)$, aspek pelaksanaan dan penatausahaan $\left(X_{2}\right)$, aspek pelaporan dan pertanggungjawaban $\left(X_{3}\right)$, aspek pengawasan $\left(X_{4}\right)$ dengan transparansi pengelolaan keuangan daerah( $(Y)$ pada SKPD Kabupaten Lumajang dengan keeratan hubungan $86,10 \%$. Nilai tersebut menjelaskan jika ke empat variabel aspek pengelolaan keuangan daerah tersebut meningkat 100\% maka akan cenderung meningkatkan transparansi pengelolaan keuangan daerah sebesar $86,10 \%$.

Koefisien determinasi sebesar $r^{2}=0,741$ menjelaskan transparansi pengelolaan keuangan daerah (Y) pada SKPD Kabupaten Lumajang hanya 74,10\% dipengaruhi oleh aspek manajemen keuangan daerah, sementara selebihnya $26,90 \%$ dipengaruhi oleh faktorfaktor lainnya yang berada diluar model analisis.

\section{Hasil Pengujian Secara Simultan (Uji F)}

$H_{1}$ : Nilai $B_{1}=0,141 ; B_{2}=0,096 ; B_{3}=0,404 ;$ dan $B_{4}=0,338$, berdasarkan nilai tersebut maka $B_{1} \neq 0 ; B_{2} \neq 0 ; B_{3} \neq 0$ dan $B_{4} \neq 0\left(B_{i} \neq 0\right)$, sehingga dapat diuraikan bahwa hipotesis alternatif $\left(\mathrm{Ha}_{2}\right)$ di terima. Artinya aspek-aspek pengelolaan keuangan daerah berpengaruh terhadap transparansi pengelolaan keuangan daerah pada Satuan Kerja Perangkat Daerah Kabupaten Lumajang. 
Received: 2021-04-05 Revised: 2021-05-06

Approved: 2021-06-03

Pengujian Hipotesis Secara Parsial

$H_{2}$ : Nilai $B_{1}=0,141$, berdasarkan nilai tersebut maka $B_{1} \neq 0$, sehingga dapat diuraikan bahwa hipotesis nul $\left(\mathrm{Ho}_{2}\right)$ di tolak, dan hipotesis alternatif $\left(\mathrm{Ha}_{2}\right)$ di terima. Artinya aspek perencanaan keuangan daerah berpengaruh terhadap transparansi pengelolaan keuangan daerah pada Satuan Kerja Perangkat Daerah Kabupaten Lumajang.

$H_{3}$ : Nilai $B_{2}=0,096$ berdasarkan nilai tersebut maka $B_{2} \neq 0$, sehingga dapat diuraikan bahwa hipotesis alternatif $\left(\mathrm{Ha}_{3}\right)$ di terima. Artinya aspek penataanusahaan pengelolaan keuangan daerah berpengaruh terhadap transparansi pengelolaan keuangan daerah pada Satuan Kerja Perangkat Daerah Kabupaten Lumajang.

$\mathrm{H}_{4}$ : Nilai $\mathrm{B}_{3}=0,404$ berdasarkan nilai tersebut maka $B_{3} \neq 0$, sehingga dapat diuraikan bahwa hipotesis alternatif $\left(\mathrm{Ha}_{3}\right)$ di terima. Artinya aspek pelaporan pengelolaan keuangan daerah berpengaruh terhadap transparansi pengelolaan keuangan daerah pada Satuan Kerja Perangkat Daerah Kabupaten Lumajang.

$\mathrm{H}_{5}$ : Nilai $\mathrm{B}_{4}=0,338$, berdasarkan nilai tersebut maka $\mathrm{B}_{4} \neq 0$, sehingga dapat diuraikan bahwa hipotesis alternatif $\left(\mathrm{Ha}_{4}\right)$ di terima. Artinya pengawasan pengelolaan keuangan daerah berpengaruh terhadap transparansi pengelolaan keuangan daerah pada Satuan Kerja Perangkat Daerah Kabupaten Lumajang.

Pengaruh Aspek-Aspek Manajemen Keuangan Daerah Terhadap Transparansi Peengelolaan Keuangan Daerah pada SKPD Kabupaten Lumajang

Aspek-aspek manajemen keuangan daerah meliputi aspek perencanaan, aspek penatausahaan, aspek pelaporan dan aspek pengawasan berpengaruh terhadap transparansi pengelolaan keuangan daerah dengan nilai $r$ sebesar 0,861 . Nilai tersebut menjelaskan jika aspek perencanaan, penatausahaan, pelaporan dan aspek pengawasan mengalami kenaikan 1\% maka akan membuat transparansi pengelolaan keuangan daerah (Y) pada SKPD di Kabupaten Lumajang akan meningkat sebesar 0,861. Kemudian kemampuan keempat variabel tersebut dalam mempengaruhi transparansi pengelolaan keuangan daerah (Y) pada SKPD di Kabupaten Lumajang juga sudah sangat dominan dengan nilai $r$ square sebesar 0,741. Sementara selebihnya 25,90\% dipengaruhi oleh variabel lainnya yang berada diluar model analsisis. Dengan demikian penelitian ini terdukung oleh penelitian sebelumnya yang dilakukan oleh Ledo dan Sri (2017) dengan judul pengaruh aspek-aspek manajemen keuangan daerah terhadap transparansi pengelolaan keuangan daerah. Penelitian ini dapat mengemukakan hasil yang sama yaitu aspek-aspek manajemen keuangan daerah berpengaruh terhadap transparansi pengelolaan keuangan daerah. 
Received: 2021-04-05 Revised: 2021-05-06 Approved: 2021-06-03

\section{Pengaruh Aspek Perencanaan terhadap Transparansi Pengelolaan Keuangan Daerah}

\section{Lumajang.}

Aspek perencanaan berpengaruh terhadap transparansi pengelolaan keuangan daerah pada pada SKPD di Kabupaten Lumajang dengan nilai koefisien regresi sebesar 0,141 satuan. Nilai tersebut menjelaskan setiap meningkatnya aspek perencanaan 1 satuan maka dapat meningkatkan transparansi pengelolaan keuangan daerah pada SKPD Kabupaten Lumajang sebesar 0,141 satuan. Dengan demikian penelitian ini terdukung oleh penelitian sebelumnya yang dilakukan oleh Ledo dan Sri (2017) yang berhasil mengemukakan aspek perencanaan keuangan daerah berpengaruh terhadap transparansi pengelolaan keuangan daerah.

\section{Pengaruh Aspek Penatausahaan terhadap Transparansi Pengelolaan Keuangan Daerah Lumajang.}

Aspek penatausahaan berpengaruh terhadap transparansi pengelolaan keuangan daerah pada SKPD di Kabupaten Lumajang dengan nilai koefisien regresi sebesar 0,096 satuan. Nilai tersebut menjelaskan setiap meningkatnya aspek penatausahaan keuangan daerah sebesar 1 satuan maka dapat meningkatkan transparansi pengelolaan keuangan daerah pada SKPD Kabupaten Lumajang sebesar 0,096 satuan. Dengan demikian penelitian ini terdukung oleh penelitian sebelumnya yang dilakukan oleh Ledo dan Sri (2017) yang berhasil mengemukakan aspek penatausahaan keuangan daerah berpengaruh terhadap transparansi pengelolaan keuangan daerah.

\section{Pengaruh Aspek Pelaporan terhadap Transparansi Pengelolaan Keuangan Daerah Lumajang.}

Aspek pelaporan berpengaruh terhadap transparansi pengelolaan keuangan daerah pada SKPD di Kabupaten Lumajang dengan nilai koefisien regresi sebesar 0,404 satuan. Nilai tersebut menjelaskan setiap meningkatnya aspek pelaporan dan pertanggungjawaban sebesar 1 satuan maka dapat meningkatkan transparansi pengelolaan keuangan daerah pada SKPD Kabupaten Lumajang sebesar 0,404 satuan. Dengan demikian penelitian ini terdukung oleh penelitian sebelumnya yang dilakukan oleh Ledo dan Sri (2017) yang berhasil mengemukakan aspek pelaporan keuangan daerah berpengaruh terhadap transparansi pengelolaan keuangan daerah. 
Received: 2021-04-05 Revised: 2021-05-06 Approved: 2021-06-03

Pengaruh Aspek Pengawasan terhadap Transparansi Pengelolaan Keuangan Daerah Lumajang.

Aspek pengawasan berpengaruh terhadap transparansi pengelolaan keuangan daerah pada SKPD di Kabupaten Lumajang dengan nilai koefisien regresi sebesar 0,338 satuan. Nilai tersebut menjelaskan setiap meningkatnya aspek pengawasan sebesar 1 satuan maka akan dapat meningkatkan transparansi pengelolaan keuangan daerah pada SKPD Kabupaten Lumajang sebesar 0,338 satuan. Dengan demikian penelitian ini terdukung oleh penelitian sebelumnya yang dilakukan oleh Ledo dan Sri (2017) yang berhasil mengemukakan aspek pengawasan keuangan daerah berpengaruh terhadap transparansi pengelolaan keuangan daerah.

\section{KESIMPULAN}

Berdasarkan hasil penelitian dan pembahasan tentang pengaruh aspek manajemen keuangan daerah terhadap transparansi pengelolaan keuangan daerah di Kabupaten Lumajang maka dapat disimpulkan beberapa kesimpulan adalah: pertama, aspek perencanaan, aspek penatausahaan, aspek pelaporan dan aspek pengawasan keuangan daerah berpengaruh terhadap transparansi pengelolaan keuangan daerah pada SKPD Kabupaten Lumajang. Kedua, peran variabel aspek manajemen keuangan daerah sudah sangat dominan dalam mempengaruhi transparansi pengelolaan keuangan daerah pada SKPD Kabupaten Lumajang. Ketiga, dari hasil koefisien determinasi sebesar $r^{2}=0,741$ menyimpulkan bahwa transparansi pengelolaan keuangan daerah (Y) pada SKPD Kabupaten Lumajang dipengaruhi oleh aspek manajemen keuangan daerah sebesar 74,10\%, sementara selebihnya $26,90 \%$ dipengaruhi oleh faktor-faktor lainnya seperti pemeriksaan, regulasi, ketaatan pada aturan hukum serta faktor lainnya.

\section{DAFTAR PUSTAKA}

Adisasmita, Rahardjo (2011) Manajemen Pemerintah Daerah. Graha Ilmu, Yogyakarta.

Arif Miirian Sjofyan et.al (2016) Menajemen Pemerintahan. Tanggerang: Universitas Terbuka Arikunto Suharsimi (2009). Prosedur Penelitian. Reneka Cipta, Jakarta.

Bastian, Indra (2012) Akuntansi Sektor Publik: Suatu Pengantar. Erlangga, Jakarta.

Dethan Stevany Hanalyna (2016) Efektivitas Dan Efisiensi Pengelolaan Keuangan Daerah Provinsi Nusa Tenggara Barat Media Bina Ilmiah Volume 10, No. 12 Fakultas Ekonomi Universitas Mahasaraswati Mataram

Fahrojih dan Najih (2016) Menggungat Peran DPR dan BPK Dalam Reformasi Keuangan Negara, Jakarta: TRANS 
Received: 2021-04-05 Revised: 2021-05-06 Approved: 2021-06-03

Halim, Abdul, \& Muhammad Iqbal, (2013). Pengelolaan Keuangan Daerah. UPPSTIM YKPN. Edisi ketiga

Khairudin dan Rina Erlanda (2016) Pengaruh Transparansi Dan Akuntabilitas Laporan Keuangan Pemerintah Daerah (LKPD) Terhadap Tingkat Korupsi Pemerintah Daerah (Studi Pada Pemerintah Kota Se-Sumatera) JURNAL Akuntansi \& Keuangan Volume 7, Nomor 2 Universitas Bandar Lampung, Lampung.

Lucy Auditya dan Husaini Lismawati (2013 ) Analisis Pengaruh Akuntabilitas Dan Transparansi Pengelolaan Keuangan Daerah Terhadap Kinerja Pemerintah Daerah Jurnal Fairness Volume 3, Nomor 1, Program Magister Akuntansi Universitas Bengkulu.

Nopriansyah Putra et.al (2016) Pengaruh Pengelolaan Keuangan Daerah, Akuntabilitas Dan Transparansi Terhadap Kinerja Pemerintah Daerah Dengan Pengawasan Sebagai Variabel Moderating Pada Provinsi Sumatera Utara Jurnal Ekonom, Vol 19, No 4, Program Magister Akuntansi USU, Medan

Nordiawan Deddi dan Hertianti (2012) Akuntasi Sektor Publik, Salemba Empat, Jakarta.

Pamungkas, Bambang (2013) Dasar-dasar Manajemen Keuangan Pemerintah Daerah, Bandung: Kesatuan Press

Pasaribu. FJ.(2011) Pengaruh Penyajian Laporan Keuangan SKPD Dan Aksesibilitas Laporan Keuangan SKPD Terhadap Transparansi Dan Akuntabilitas Pengelolaan Keuangan SKPD. Tesis. Program Pasca Sarjana Univ.Sumatera Utara, Medan.

Rahmanurrasjid, Amin. (2011) .Akuntabilitas dan Transparansi Dalam Pertanggung jawaban Pemerintah Daerah Untuk Mewujudkan Pemerintahan Yang Baik di Daerah. Tesis. Semarang. Program Magister Ilmu Hukum-Universitas Diponegoro, Yogyakarta.

Republik Indonesia, Peraturan Menteri Dalam Negeri Nomor 21 Tahun 2011 Tentang Perubahan Kedua Atas Peraturan Menteri Dalam Negeri Nomor13 Tahun 2006 Tentang Pedoman Pengelolaan Keuangan Daerah.

Republik Indonesia, Peraturan Pemerintah No. 8/2006 tentang Pelaporan Keuangan dan Kinerja Instansi Pemerintah.

Republik Indonesia, Peraturan Pemerintah Nomor 58 Tahun 2005 Tentang Pengelolaan Keuangan Daerah.

Republik Indonesia, Undang- Undang No. 17/2003 Tentang Keuangan Negara.

\section{Copyright (c) 2021 Ari Rachmad}

This work is licensed under a Creative Commons Attribution-NonCommercial 4.0 International License. 